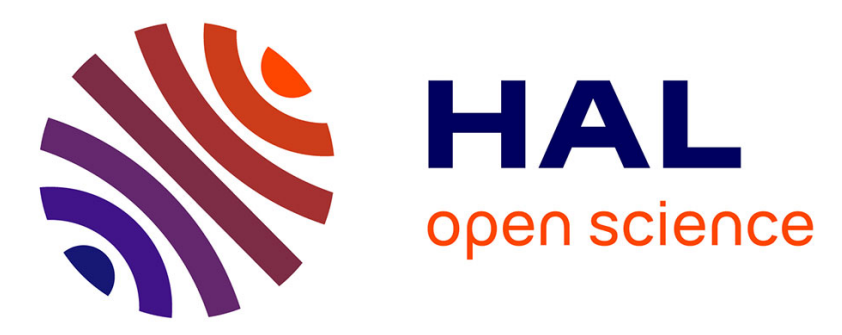

\title{
Multiple forms of applications and impacts of a design theory -ten years of industrial applications of C-K theory
}

\author{
Armand Hatchuel, Pascal Le Masson, Benoit Weil, Marine Agogué, Akin
}

Kazakçi, Sophie Hooge

\section{- To cite this version:}

Armand Hatchuel, Pascal Le Masson, Benoit Weil, Marine Agogué, Akin Kazakçi, et al.. Multiple forms of applications and impacts of a design theory -ten years of industrial applications of $\mathrm{C}-\mathrm{K}$ theory. Impact of Design Research on Industrial Practice - Tolls, Technology and Training, 2015, 10.1007/978-3-319-19449-3_12 . hal-01200460

HAL Id: hal-01200460

https://hal-mines-paristech.archives-ouvertes.fr/hal-01200460

Submitted on 17 Sep 2015

HAL is a multi-disciplinary open access archive for the deposit and dissemination of scientific research documents, whether they are published or not. The documents may come from teaching and research institutions in France or abroad, or from public or private research centers.
L'archive ouverte pluridisciplinaire HAL, est destinée au dépôt et à la diffusion de documents scientifiques de niveau recherche, publiés ou non, émanant des établissements d'enseignement et de recherche français ou étrangers, des laboratoires publics ou privés. 
Hatchuel, A., Le Masson, P., Weil, B., Agogué, M., Kazakçi, A. O., and Hooge, S. (2015). "Mulitple forms of applications and impacts of a design theory - ten years of industrial applications of C-K theory." Impact of Design Research on Industrial Practice - Tools, technology, and

Training, A. Chakrabarti et U. Lindemann, eds., Springer, Munichpp. 189-209

\title{
Multiple forms of applications and impacts of a design theory - ten years of industrial applications of $\mathrm{C}-\mathrm{K}$ theory
}

\author{
Armand Hatchuel, Pascal Le Masson, Benoit Weil, Marine Agogué, Akin \\ Kazakçi, Sophie Hooge
}

\begin{abstract}
C-K theory has been developed by Armand Hatchuel and Benoit Weil and then by other researchers since 1990s. In this paper we show that its very abstract nature and its high degree of universality actually supported a large variety of industrial applications. We distinguish three types of applications: 1) C-K theory provides a new language, that supports new analysis and descriptive capacity and new teachable individual models of thoughts; 2) $\mathrm{C}-\mathrm{K}$ theory provides a very general framework to better characterize the validity domain and the performance conditions of existing methods, leading to potential improvement of these methods; 3) C-K theory is the conceptual model at the root of new design methods that are today largely used in the industry.
\end{abstract}

\section{Introduction:}

In the 80 s there has been great debates in Germany to know whether Systematic Design was applied and efficient in practice (Ehrlenspiel 1995; Heymann 2005). Many empirical studies were made to asses the use and efficient of the methods. It appeared that, when working alone on a design problem, a designer didn't fully follow the methods or was more efficient when he did not fully follow the steps. Still, at the same period, in the industry and the companies appeared norms for engineering (see VDI Richtlinie 2221 and 2222, see the French AFNOR norm NF EN ISO 9000:2000) that were directly inspired by the systamtic design framework; the routines of project management (list of requirements, stage-gate, steps, $\mathrm{V}$-cycle,...) as well as the software and tools associated to product development relied on systematic design; the theory also inspired the organization charts and procedures used to organize collective design work like the relationship between marketing department and engineering department, between integrators and suppliers of components in complex systems, between engineering department and research labs,... Hence the language of a design theory was used as the language to organize collective action (functional description, conceptual models, embodiment,...).

More generally, the "applications" of a theory can take multiple forms. As indicated by the etymology, a theory (from the greek theorein, contemplate, observe, 
look at) is a way to look at things. As such, in a very broad sense, it provides a rigorous language for action. This is not only true for design theory. For instance, when Steinmetz, by General Electric, used complex numbers to design electric circuits, he actually used a theory to "look at" electrical circuits with specific lenses. Decision theory provides us another example of multiple forms of applications. Of course it was "transformed" into methods (decision trees for risk management, real options,...). It was also used to create new organizational roles and procedures (manager as decision-maker, the role of experts in decisionmaking,...). As a general language of performance, it helped to discuss the rationality of past decisions or the validity of empirical methods (in statistics it provided firm ground for the theory of tests). Even more: as a very general, transdisciplinary paradigm, it had an impact in other disciplines; the theory diffused for example in management, economics, or neuroscience, where it helped, for instance, to analyze decision making situations or to diagnose "bias" in decision making. These new results led in turn to other, polymorphic applications.

In a nutshell, evaluating the industrial applications and impact of a design theory might consist in evaluating four dimensions:

1. Improvement of analytical and descriptive capacities

2. Improvement and positioning of existing methods and processes. The theory helps to characterize (and occasionally increase) the validity domain of (empirical) methods and processes.

3. Development of new tools and processes. These tools and processes will, for instance, address situations that are out of the validity domain of the available methods.

4. Impact on other disciplines and on design professions. We trace here the diffusion of the theory in other academic disciplines and how the theory is taught to professionals who could, in turn, develop individually or collectively lop new methods and techniques in the future.

In the following we will use this framework to analyze industrial applications and impacts of $\mathrm{C}-\mathrm{K}$ theory in the last ten years.

In a first part we remind of the origins of $\mathrm{C}-\mathrm{K}$ theory, showing that the development of the theory was stimulated by the lack of methods to address so-called innovative design. We finish this part by underlining some critical aspects of the theory. In the following parts we address the four dimensions.

To this end, we build on the work done by (Agogué and Kazakçi 2013). We gathered all the publications in blind peer-reviewed journals, as well as books, thesis, book chapters, conference papers with peer-reviews on abstracts and/or full papers and we analyzed the material regarding the four dimensions mentioned above. In this paper we don't want to describe all this material but we shall favor some cases where we were directly involved and for which we are more competent. We completed our data collection with interviews and feedbacks from students and practitioners who applied C-K methodologies and tools. 


\section{$1 \quad$ Origins and specific features of $\mathrm{C}-\mathrm{K}$ design theory}

\subsection{From product improvement to new identities of objects}

In the 1990s, several works contributed to characterize deep changes in the design of new products and services by engineering departments. Knowledge management studies (see for instance: (Blackler 1995; Hatchuel and Weil 1995)) underlined the crisis of expert knowledge; innovation management underlined the shift towards "radical", "breakthrough" or "disruptive" innovation and some indepth studies of engineering design department showed that this shift would require a deep change in the models of thought (Weil 1999). Far from being a managerial fashion, the call for "innovation" was actually a symptom of a strong change in the nature of innovation: contemporary innovation doesn't only require constant performance improvement of a fixed dominant design, but also the repeated invention of new object identities, requiring a capacity to break design rules at every level -new values, new business models, new functions, new technologies, new architectures, new design ecosystems.

Still available methods in engineering design departments and, more generally, in $\mathrm{R} \& \mathrm{D}$ organizations, had been historically thought to support so-called new product development processes. Methods like functional analysis and QFD, processes like NPD projects, stage-gate and V-cycles, organization like project / competences matrices were adapted to listen to the customer, to select the right requirements at the right level and to optimally use technical skills and competences to meet the specifications, relying on a network of suppliers and R\&D labs. Methods were available for rule-based design. But, beside this rule-based design mission, new design missions appeared that consist in exploring an innovation field, without clear customer requirement, consist in creating new knowledge instead of just using the available one, consist in breaking existing design rules precisely to explore out-of-the-box, and consist in creating new ecosystems instead of relying on the existing one. For this "innovative design", the usual methods, processes and organizations were at their limits.

This analysis stimulated the development of a design theory that would be a model of thought on desirable still partially unknown, undecidable objects.

\subsection{C-K theory - the dual expansion}

In 1996, when teaching design theories to MINES ParisTech students, Armand Hatchuel proposed a first formulation of C-K theory. In the following years, the formulation was strengthened, leading to multiple publications in French. In 2002, Hatchuel and Weil (2002) presented their first French conference paper exposing the main principles of C-K theory: this theory is based on the distinction between 
two expandable spaces: a space of concepts, the C-space (concepts are defined as undecidable propositions), and a space of knowledge $\mathrm{K}$. The process of design is thus defined as the co-evolution of $\mathrm{C}$ and $\mathrm{K}$ through four types of independent operators (C-C, C-K, K-C, K-K). Since the seminal English-written paper from 2003 (Hatchuel \& Weil, 2003), the features of C-K theory have been recognized as being unique for describing creative reasoning and process in engineering design, as stated by Ullah, Rashid and Tamaki (Sharif Ullah et al. 2011). Specifically, these scholars highlight the fact that one of the most noticeable features of $\mathrm{C}-\mathrm{K}$ theory is its foundation on the notion of a creative concept - a concept being an undecidable proposition with respect to the existing knowledge at the time it emerges.

In the following years, it appeared that the impact of $\mathrm{C}-\mathrm{K}$ theory was not limited to the engineering design community. For instance since 2003, the RATP, the public transport operator for the city of Paris operating the subway, has deployed C-K driven tools (Hatchuel, Le Masson \& Weil, 2009): they indeed use regularly the KCP approach, a method for collective creative design, on subjects such as "Bus Rapid Transit", "21st century Metro", "Local bus services", "Walking” or "Night bus stations". Another symptom of the impact in the industrial field: in 2010, the French company Thales, which designs systems and services for the aerospace, published a book on its design process and advocated $\mathrm{C}-\mathrm{K}$ theory as a way to organize innovative design activities (Defour et al. 2010). In management and organization, so many works were done that in 2012, a paper was presented in the French International Management Conference on the impact of C-K theory in management science over the last 10 years (Benguigui 2012).

To present these impacts in more depth we will address four different dimensions: 1- Improvement of analytical and descriptive capacities; 2- Improvement and positioning of existing methods and processes; 3- Development of new tools and processes and 4- Impact on other disciplines and on design professions.

\section{C-K theory, a new language to describe and analyse innovative design activities}

$\mathrm{C}-\mathrm{K}$ provides researchers and practitioners with a framework to describe, analyse and evaluate innovative design processes. In his conference paper retracing the influence of C-K on management research, Benguigui (Benguigui 2012) stated that $\mathrm{C}-\mathrm{K}$ theory is an excellent theoretical framework to explain the process of early phases of innovation, to interpret the misunderstandings (or quiproquos) in management context, to develop managerial tools and to relate the history of inventions. We won't detail here all the analyses made with $\mathrm{C}-\mathrm{K}$ theory, the reader can refer for instance to (Silberzahn and Midler 2008; Eris 2005; Zeiler and Savanovic 2009; Pialot et al. 2011; Sharif Ullah et al. 2011; Elmquist and Segrestin 2009; Elmquist and Le Masson 2009; Gillier et al. 2010; Lenfle 2012) 
As an illustration we focus on the evaluation of innovative projects and projects portfolios.

\subsection{Innovative projects evaluation}

$\mathrm{C}-\mathrm{K}$ theory provides a relevant analytical framework to evaluate innovative projects, since it helps to analyse rigorously the multiple outputs of innovative design projects: with the C-K framework it is self-evident that the outputs are not limited to a final artifact (e.g. a product), but also the knowledge produced during the design process and all the other concepts that didn't yet give birth to new product but might be reuse in the future (Figure 1).
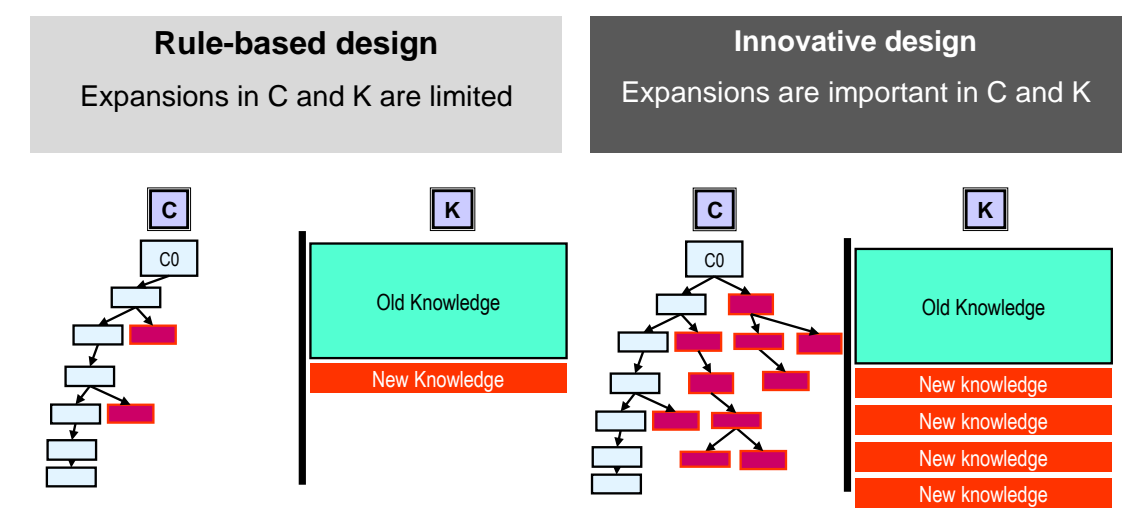

Evaluation criteria:

Quality, Cost, Delay

Evaluation criteria: Variety, Value, Originality, Robustness

Figure 1: Innovative project evaluation: contrasting product development and innovative design

This kind of evaluation spread in many firms (Elmquist and Le Masson 2009; Hooge 2010; Hooge and Hatchuel 2008). More sophisticated evaluation criteria were proposed: for instance the V2OR scale (variety, value, Robustness, originality) uses creativity measures and rule-based design criteria to analyze innovative design outputs in C and K (Gardey de Soos 2007; Le Masson and Gardey de Soos 2007; Le Masson et al. 2010): 
- the outputs of an innovative project in C can be evaluated in term of Originality and Variety, which are close to Guilford criteria: Fluency, Variety, Oringiality, with the great advantage that $\mathrm{C}-\mathrm{K}$ theory enables to measures originality as an expansive partition (avoiding the difficulty of Guilford measure where the measure of originality requires a large sample since it is measured as a low frequency proposal in a set of proposals).

- The outputs in K can be evaluated in term of Value and Robustness, the first one indicating knowledge that helps to regenerate the possible set of values for stakeholders (new potential functional requirements) whereas the second one relates to knowledge on the new means of action (new possible design parameters) that are now available to the designer.

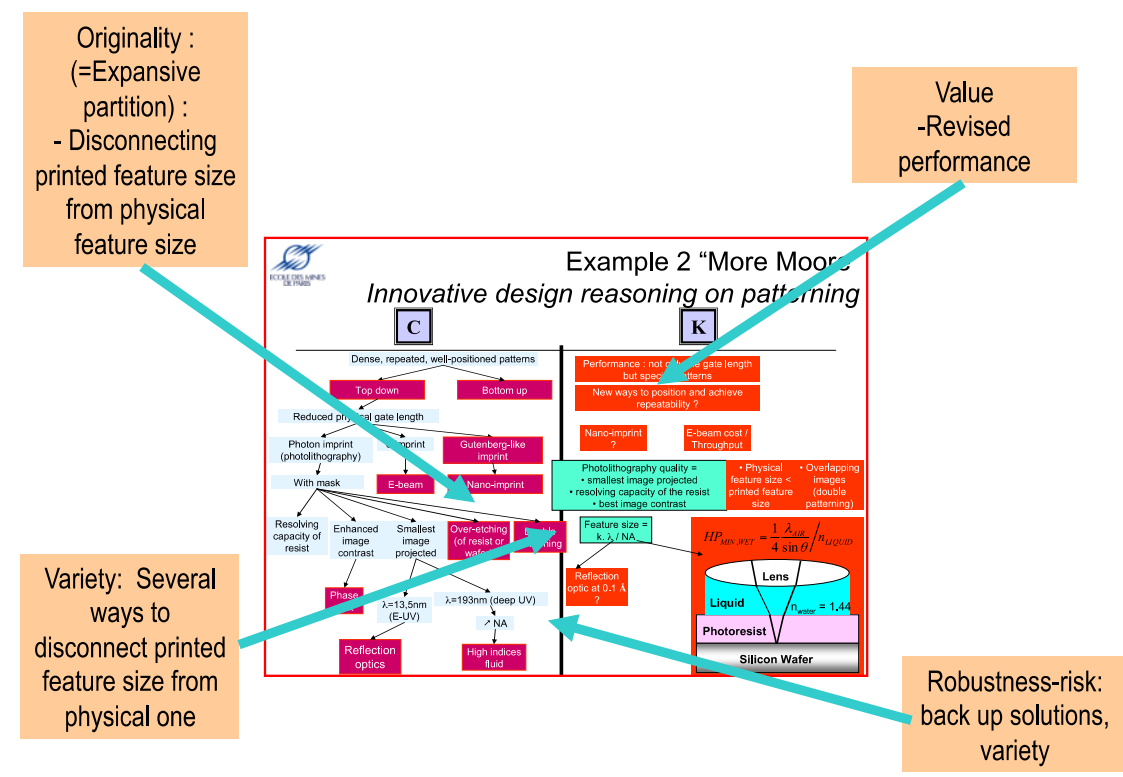

Figure 2: Evaluation criteria for innovative design explorations: V2OR (Variety, Value, Originality, Robustness)

\subsection{Evaluating a portfolio and its positioning}

Based on C-K theory, new analytical instruments were developed, like C-K referential (Ben Abbes 2007; Agogué et al. 2012; Agogué 2012). Given an innovation field, such a referential maps all the alternatives that can be imagined by a group of C-K experts using a set of expert knowledge - as large as possible. It has be shown that such a referential is significantly broader that classical roadmaps 
and included unexplored but identified paths as well as paths in the unknown (Agogué et al. 2012).

This tool was used in multiple cases such as " 2 wheelers safety", "biomass energy" or "autonomy of elderly people" (see figure 3). It helped to diagnose orphan innovation situations: positioning the projects actually funded in an ecosystem on the referential reveals large unexplored areas in the innovation field. Even more: it is possible to show that one of the common features of all the unexplored areas is that they require at least one expansive partition (a partition in $\mathrm{C}$ that uses an unusual property from $\mathrm{K}$ ), whereas the explored areas tend to correspond to restrictive partitions (a partition in C that uses usual properties from K) (Agogué et al. 2012).

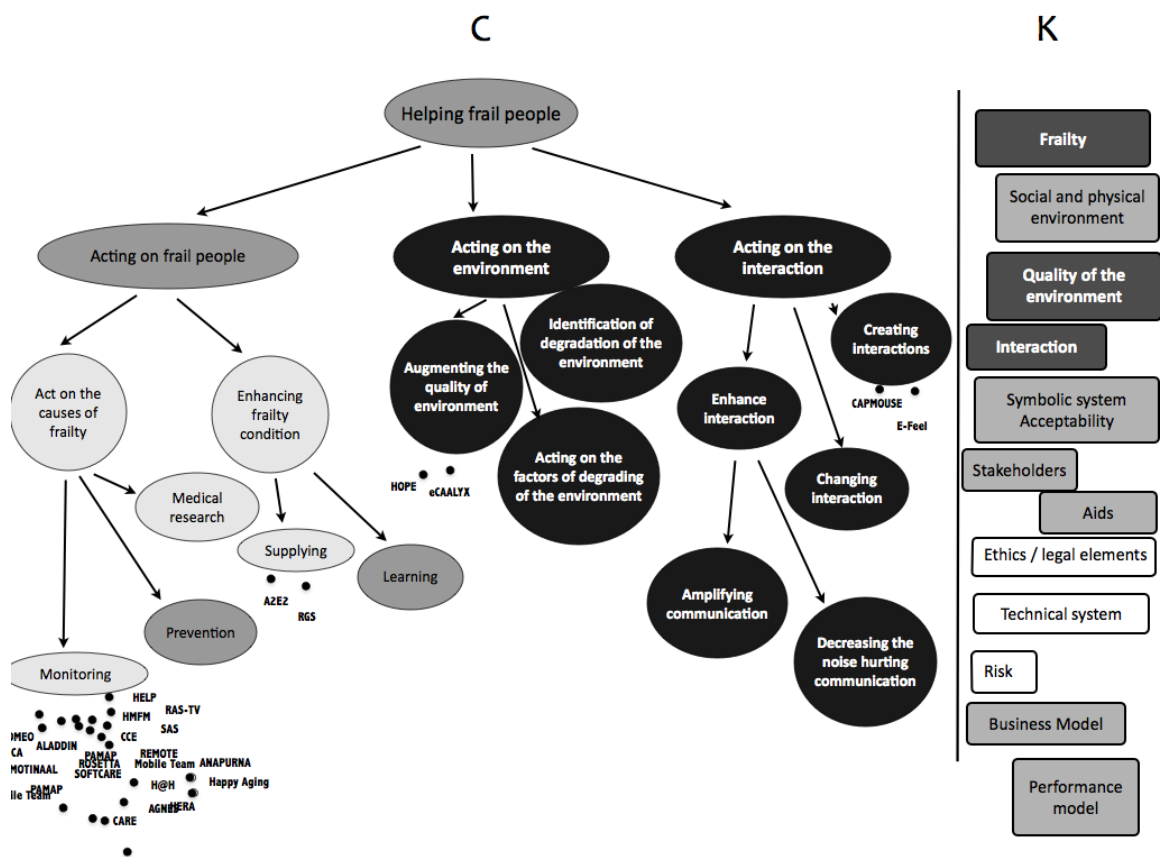

Figure 3: C-K referential in the case of "autonomy of elderly people"

This kind of technique was also used to analyze the "roadmaps" elaborated by working groups of the International Technology Roadmap for Semiconductors (see figure 4). In this case, the diagnosis showed that the working group roadmaps were able to cover very large areas of the $\mathrm{C}-\mathrm{K}$ referentials, hence avoiding orphan innovation (Cogez et al. 2011; Cogez et al. 2013). 


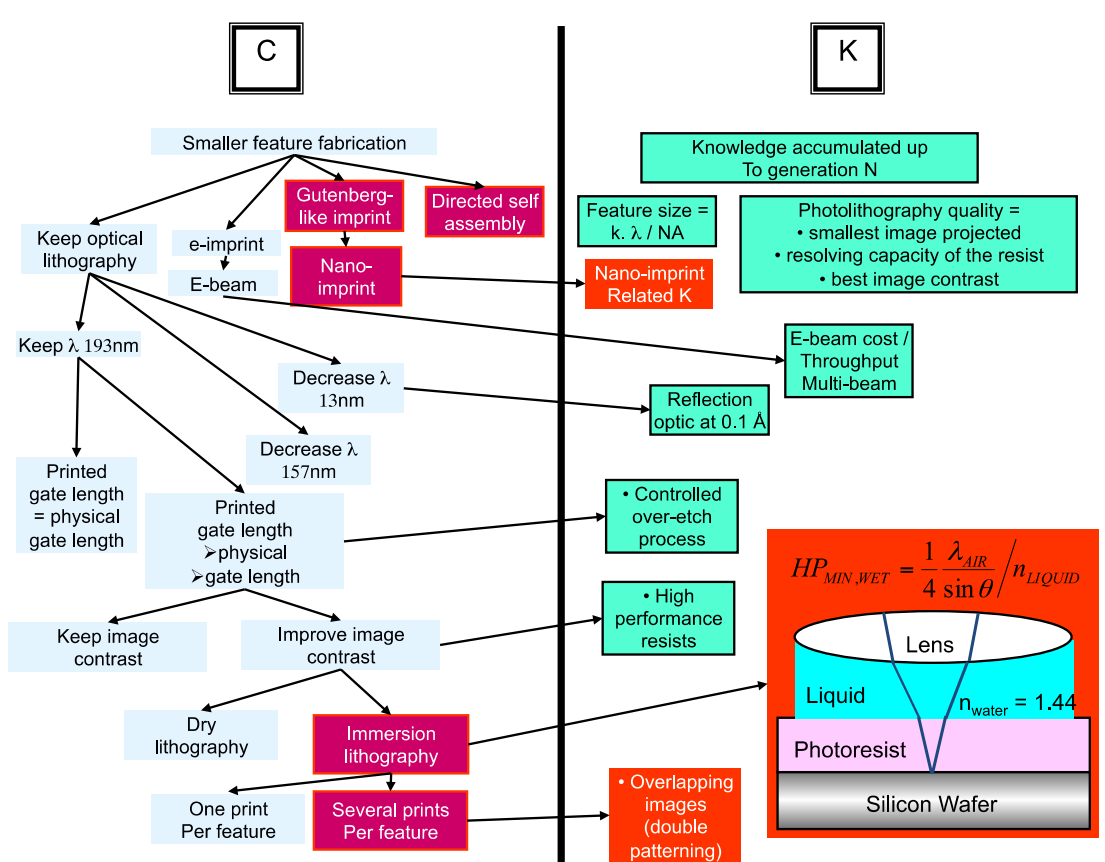

Figure 4: C-K referential of the ITRS roadmap for photolythography

\subsection{Tuning breakthrough}

Another refinement of $\mathrm{C}-\mathrm{K}$ graphs led to structure the C-graph depending on the "heredity" degree of the attributes: the higher the attribute in the C-tree, the most hereditary it is, ie the oldest and the most difficult to break (see figure 5). 


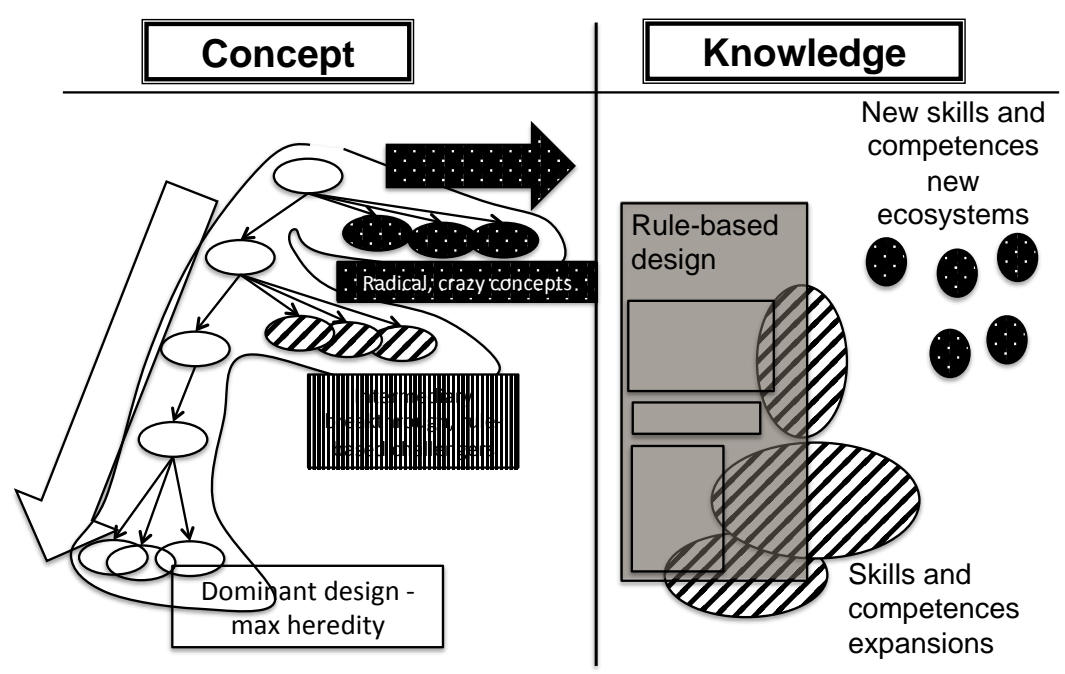

Figure 5: Tuning the breakthrough with $\mathrm{C}-\mathrm{K}$ graphs

This criteria supports an order in the C-K graph. This kind of ordering is illustrated by (Brogard and Joanny 2010), who realized a C-K graph associated to the concept "engines for green aircraft in 2025" (see figure 6). Their work encompassed improvement of jet engines as well as gliders or other complex systems that would require to change not only the engine but also the aircraft, the air transportation companies and airport organization, ie the whole ecosystem. The first solution is low in the graph, many attributes are kept unchanged, from the highest hereditary to the lowest one; the second one is very high in the graph, keeping very few attributes from the existing solutions. 


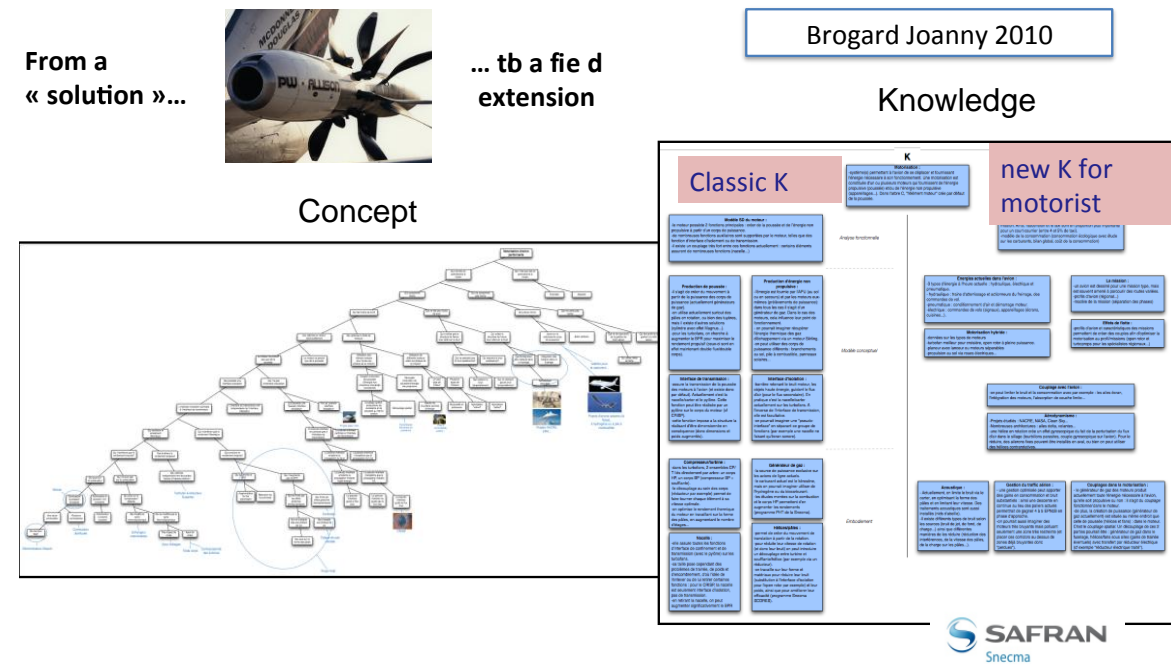

Figure 6: C-K graph associated to the concept "engine for green aircraft

This kind of graph helps to analyze the level of breakthrough that an innovative project implies, compared to its neighbor in such a C-graph. For instance, the work of Brogard \& Joanny (Brogard and Joanny 2010) helped to show the level of originality of the concept of "open rotor" (see figure 7). Beyond this analytical power, such graphs also leads to tune the level of breakthrough in a portfolio of projets. 


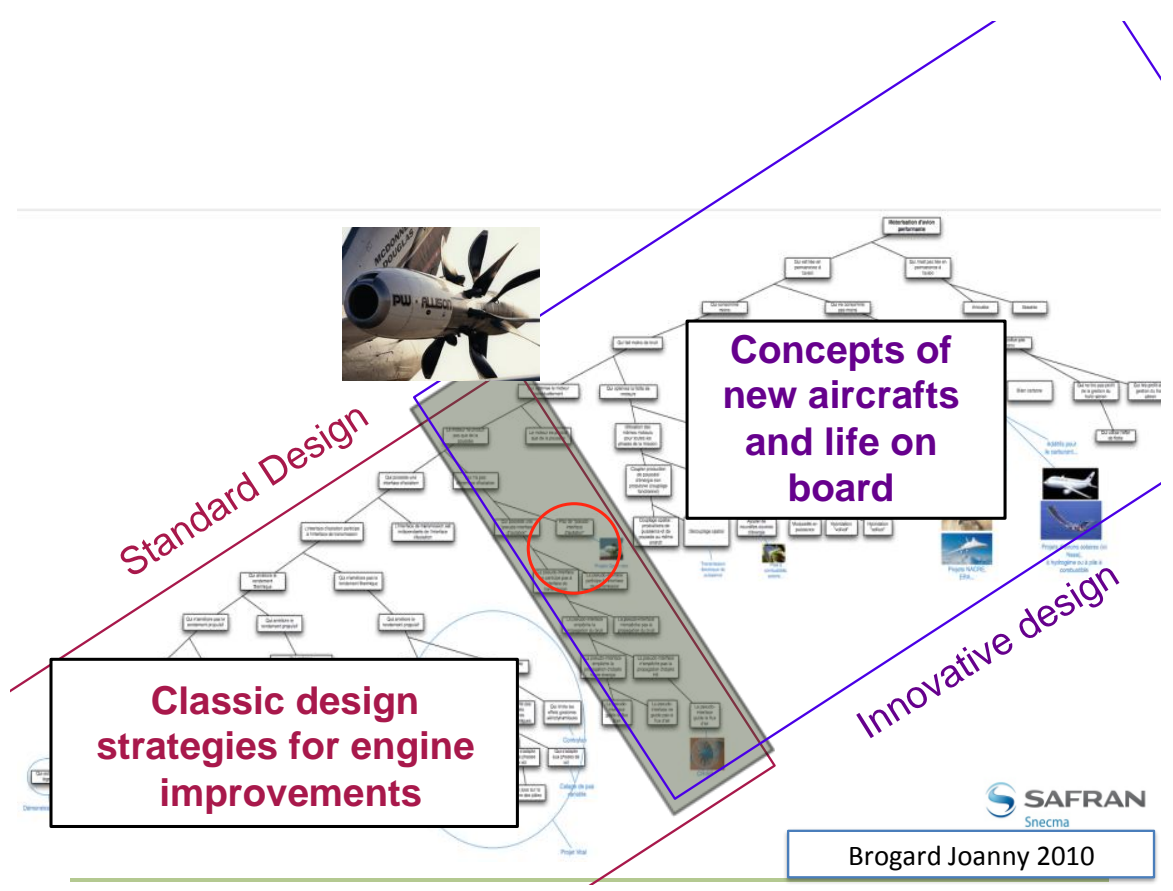

Figure 7: C-K graph to position the "open rotor" in the innovation field of "engines for green flights"

\section{$3 \quad \mathrm{C}-\mathrm{K}$ theory, a framework to position and develop existing design methods and processes}

As a general design theory, $\mathrm{C}-\mathrm{K}$ theory helped to analyze exiting design methods. Casting any method into the $\mathrm{C}-\mathrm{K}$ theory leads to uncover and clarify some implicit aspects: hypothesis on the available knowledge, on the user capacities, on the kind of concept that can be expected from the method... Even more: it can lead to propose improvements to these methods.

Let's mention some examples:

- $\quad$ C-K was used to analyze Advanced Systemic Inventive Thinking (ASIT, a special method derived from TRIZ); it helped to underline the critical issue of the "closed world assumption", it showed that ASIT was a specific way to be creative "while staying in the box" and it led to propose improvements to ASIT (Reich et al. 2010)

- $\quad$ C-K was used to compare Parameter Analysis to other forms of Conceptual Design (Kroll 2013). It then led to show that Parameter Analyse relied on a specific way to evaluate concepts, and that, as such, it was actually an extension of the well-known Branch \& Bound algorithm to Design cases (Kroll et al. 2013). 
- In an historical perspective, C-K helped to compare some of the theories that led to the systematic design framework. It led to reveal the critical features of systematic design, namely: a structured language of the unknown (and not only the "known" as tend to do scientists in a modeling perspective) and a constant effort to improve the generativity of the theories (Le Masson and Weil 2013).

- In (Shai et al. 2009, 2013), the use of the Infused Design methodology in the creative scientific discovery process is modelled with C-K theory, leading to a deeper understanding of both Infused Design and C-K theory.

- In (Lenfle 2012), Lenfle uses C-K theory to analyze and evaluate the methods used in breakthrough projects. He revealed that, contrary to conventional wisdom, these methods were strongly different from project management techniques like PERT and stage-gate processes; and he was able to clarify some specific features of these very original methods for breakthrough innovation projects.

- Studying the most recent CAD tools for industrial designers, PierreAntoine Arrighi identified critical features with the help of C-K theory (Arrighi et al. 2013). For instance, he uncovered a logic of "acquired creativity": whereas it is often considered that there is a trade off between robustness and creativity, some CAD tools managed to simultaneously increase the originality and the robustness of a design (Arrighi et al. 2012).

\section{$4 \quad$ C-K theory, a conceptual model to develop methods and processes for innovative design situations}

Beyond this analytical perspective, C-K theory was also used as a "conceptual model" to design methods and processes for managing innovative design processes. Here again it is not possible to account exhaustively for all the methods that were developed. We will just mention some examples in three families: the methods to manage innovative design processes; the methods to organize innovative design in companies; and the methods to support innovative design in ecosystems (beyond the single firm).

\subsection{Methods for innovative design processes: $K C P, C$-K invent, C-K expert, $C-K$ for the design of Generic Technologies,...}

$\mathrm{KCP}$ is a method derived from $\mathrm{C}-\mathrm{K}$ theory to support innovative design processes that need to involve many participants like experts, users, researchers, engineers, designers, customers.... C-K theory helped to analyze the limits of traditional methods of collective creativity (Hatchuel et al. 2009): methods of group 
creativity (like more or less sophisticated brainstorming) tend to lead to a consensus with very few breakthrough; by constrast, task force create breakthrough but due to their limited size they often lack expert inputs. The theory was used to overcome these risks, while creating a linear process for innovative design. $\mathrm{KCP}$ is a "linear approximation" of a C-K process:

- the K phase is introduced to create a common knowledge base, that will support venture into the unknown. More than a state of the art it has also to be a state of the non-art, ie a work on the limits of available knowledge, on anomalies and "holes" in knowledge.

- During C-phase, participants generate concepts in a guided way; relying on $\mathrm{C}-\mathrm{K}$ graphs, the leading team will support divergence in the exploration to avoid fixations.

- During P-phase, participants will structure an agenda of action. Aware of the interdependencies between all the paths they will set of portfolio of action that should cover all the imagined alternatives (with a fixed budget).

As shown by in-depth research studies made on KCP (Arnoux 2013; Elmquist and Segrestin 2009), one of the most surprising features of this method is that rigor, rationality and control do not limit participant's creativity whereas they drastically increase its scope and value in a structured way. Moreover, the collaborative work favours the innovation process. These claims as well as the creative power of KCP workshops have been confirmed through field experiments conducted in several projects (Metros of the future with RATP, new types of cockpits with Thalés, new home networking with Sagem and several others with Vallourec, Volvo, etc.). More than $30 \mathrm{KCP}$ were run with 10 companies.

$\mathrm{C}-\mathrm{K}$ theory was also used to develop a method to design patents, C-K invent (Felk 2011; Felk et al. 2011) or a method to involve experts in "rule-breaking" processes, $\mathrm{C}-\mathrm{K}$ expert.

More recently C-K theory was used to manage risk in "double unknown" situations: when market and technologies are unknown, techno-push and market-pull strategies are impossible. It is often said that such situations are doomed to (costly) trial and error or, a bit more optimistic, "try and learn". Still advances in design theory, and in particular the logic of K-reordering in $\mathrm{C}-\mathrm{K}$ theory, helps to figure out strategies to design generic technologies that break the fatality of low market and technology probability (Kokshagina et al. 2013a). Interestingly enough, this method shows that the risk management in a design perspective doesn't consist in uncertainty reduction but in structuring the unknown and designing independences (Le Masson et al. 2013).

\subsection{Innovative design organizations: $R I D, R c, D c, .$.}

In an organizational perspective, C-K theory helps to clarify that innovative design is a specific model of action, different from New Product Development and Research: whereas Research can be characterized a controlled process of know- 
ledge creation and Development as a process that maximizes knowledge reuse and minimize knowledge creation in design, C-K theory helps to cover a large span of design processes that include Research and Development but might also go beyond R\&D, including activities that consist in breaking design rules intentionally, aiming at generating original objects. C-K theory helps to understand critical aspects of innovative design action; it enlightens what has to be managed (explore largely and rigorously the $\mathrm{C}$-space, relates creativity to knowledge and knowledge creation,...) and hence helps to define the mission, role, time horizon for action, resources or performance of an "innovation director" or an innovation department. The theory helped to distinguish innovative design from $\mathrm{R}$ and $\mathrm{D}$ and to organize the new "R-I-D", ie the shift from R\&D organization to R-I-D organizations, where I stands for innovative design (Hatchuel et al. 2006; Le Masson et al. 2010).

The growth of innovative design activities has also led to the emergence of new forms of research. Based on C-K theory, it was possible to characterize (analyze and support) a new form of advanced research: this so-called "conceptive research" consists in mapping rigorously a concept $\mathrm{C} 0$, as exhaustively as possible. They are many similarities with "research": we characterized research as a controlled process of knowledge production (where the value of research is more on control than on the use of knowledge); conceptive research is as controllable as research, but, contrary to modeling and optimizing, conceptive research is made on $\mathrm{C}$ and not on $\mathrm{K}$, ie it is done on unknown objects instead of known ones (Felk 2011; Le Masson et al. 2012b, c). C-K theory helped to clarify the performance, the organization and the resources relevant for conceptive research.

Scholars also identified a new form of development, conceptive development Dc. Dc appears in situations where both markets and technologies are unknown. In this situation of double unknown, the usual development processes are not feasible (no clear target, no available proven technologies...); still C-K theory helped to identify a specific strategy consisting in developing a generic technology that target a set of potential markets; paradoxically, this activity in double unknown can be organized to become almost as predictable and controlled that a usual NPD process (Kokshagina et al. 2013b; Kokshagina et al. 2013a).

\subsection{Colleges and architects of the unknown}

C-K theory helped to analyze and improve new forms of inter-firm collaborations at ecosystem level. On the one hand, it led to uncover the logic of "unlocking rules": scholars have long analyzed how rules might lead to "path dependency" and provoke "lock in"; with C-K theory it was possible to show that some rules might be unlocking and can help organize forms of path creation. These rules were associated to specific organizational forms, so-called "colleges for the unknown", ie ecosystem level collaborations where experts don't share knowledge but discuss on the agenda of open questions, ie the unknown in the field (Le Masson et al. 2012d). 
On the other hand, C-K helped identify specific intermediary actors of open innovations, that were called architects of the unknown. Contrary to brokers who support the exchange of knowledge in pre-existing networks of seekers and solvers, the architects of the unknown organize collective action when there are no clear interests and no pre-identified seekers and solvers (Agogué et al. 2013c). C$\mathrm{K}$ theory was also used to support new forms of organizations by these architects, enhancing their capacity to "visualize the invisible", to creatively solve conflicts, to design new identities and new ad'hoc expert networks (Agogué et al. 2013a); it was also used to clarify their way to efficiently deal with expectations, avoiding technological bubbles by managing so-called "generative expectations" (Le Masson et al. 2012a).

\section{C-K theory, a transdisciplinary impact, on academic disciplines and design professions}

Being models of thoughts, design theories have a great potential of transdisciplary impact. This means that the formalism can diffuse into other discipline and be reused in many different fields. Moreover it can also diffuse to many professional groups, like engineers but also industrial designers or business managers who, in turn will use it to develop ad'hoc methods and processes. Hence the importance to analyze the impact of the theory in professionals education and in academic disciplines.

\subsection{Teaching de-fixation to professionals}

C-K theory formalisms are taught today in different countries (France, Sweden, US, UK, Israel, Tunisia) in various contexts: engineering schools, management schools, business schools, design curricula, entrepreneurship schools, and universities... Over the last five years, the team from Ecole des Mines de Paris has supervised closely 41 master students doing internships using C-K theory in French institutions and firms (big firms, medium size firms and start-ups). They worked in sectors such as transports, energy, food, NTIC, health, nanotechnologies and urbanism.

The impact of this kind of education was studied by researchers (Hatchuel et al. 2008; Dym et al. 2005; Hatchuel et al. 2011) and recent experiments based on a cognitive perspective showed that this kind of teaching significantly increase the capacity of students to resist to fixation (Agogué and Cassotti 2012).

Observations through empirical investigations (interviews with consultants specialized on $\mathrm{C}-\mathrm{K}$ methodologies, industrial partners, students) show that today, the diffusion and adoption of $\mathrm{C}-\mathrm{K}$ theory through teaching and companionship leads to the emergence of practices outside of the scope of the Design Theory and 
Methods for Innovation team at Mines ParisTech. Those practices are indeed adapted very finely to the technological, social and organizational contexts of their applications.

\section{$5.2 \quad$ Impact on disciplines, beyond engineering design}

The implications of C-K theory have disseminated in many academic fields (see figure 8), such as creativity research (Le Masson et al 2011; Hatchuel et al 2011), data mining and knowledge management (Ondrus, Pigneur 2009; Poelmans et al 2009; Goria 2009), history of engineering design (Le Masson \& Weil 2010a; 2010b), psychology and cognition (Hatchuel et al 2011; Agogué et al, 2011), ecology (Berthet, Bartignolle and Segrestin, 2012; Berthet et al 2012), philosophy (Schmid, 2009; Schmid, Mambrini-Doudet \& Hatchuel, 2011) and economics (Colasse \& Nahkla, 2011; Nahkla \& Colasse, 2011).

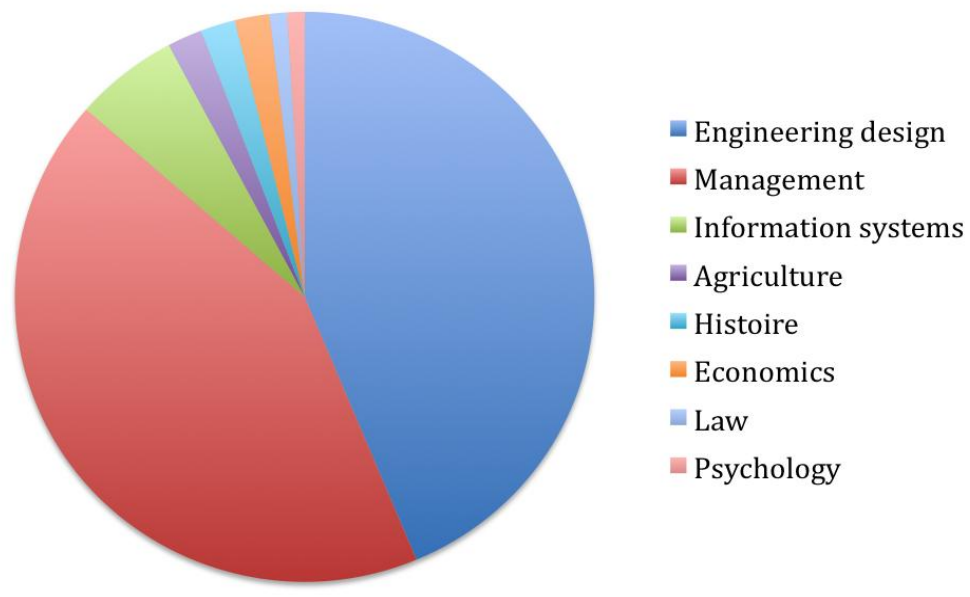

Figure 8: Repartition of the publications on $\mathrm{C}-\mathrm{K}$ theory in diverse academic fields (end of 2012)

In the domain of cognition, Hatchuel et al. (2011) have shown how C-K theory can help overcome fixation effect, i.e. being fixed on a small number of solutions, binding creativity. They stated that the outcomes of $\mathrm{C}-\mathrm{K}$ theory based design curriculum can be measured, being a possible catalyst while teaching creative thinking to students with the ability of creative thinking. Building on the notion of fixation effect, Agogué et al (Agogué et al. 2013b) claimed that there are two types of examples that $\mathrm{C}-\mathrm{K}$ theory helps to characterize: (1) restrictive examples that do not change the definition or the attributes of the object, and (2) expansive examples that modify its identity by adding unexpected attributes. Using an experimental protocol, they showed in the field of cognitive psychology that the solutions proposed by the group exposed to restrictive example are less original than those given by groups exposed to expansive examples. 
In ecology, a stream of research focuses on identifying and exploring effective solutions for integrating development of agriculture and conservation of biodiversity at a landscape scale. Berthet, Bretagnolle and Segrestin (Berthet et al. 2011) presented a case study on an intensively farmed French cereal plain, where the reintroduction of grasslands has been proposed to protect the Little Bustard, a threatened European bird species. They analyzed the design reasoning that fostered this idea in order to highlight the innovative paths that were opened. They used C-K theory to do so, and revealed the links between the production of scientific knowledge and the generation of various solutions. It allowed them to state that specifying the ecological functions of grasslands facilitates their management.

There is today an impact of C-K theory in a branch of philosophy, called contemporary epistemology. Traditional epistemology discusses the truth or proof of truth of sciences. Contemporary epistemology is interested more in how science can create new techniques and control processes through ethics and democratic principles. Interestingly, researchers in this field have found in C-K theory an operational framework to describe processes and principles for generic epistemologies (Schmid et al 2011).

\section{Conclusion}

In this chapter we have distinguished three types of applications of the $\mathrm{C}-\mathrm{K}$ design theory: 1) C-K theory provides a new language, that supports new analysis and descriptive capacity and new teachable individual models of thoughts; 2) C-K theory provides a very general framework to better characterize the validity domain and the performance conditions of existing methods, leading to potential improvement of these methods; 3) C-K theory is the conceptual model at the root of new design methods that are today largely used in the industry. We also highlight the impact of C-K theory on other disciplines and on design professions.

All these cases reveal a shift in our contemporary societies between a "decision paradigm" dominant during the second half of the twenty century and that we can call a post-decision paradigm, " a design paradigm".

We have shown that we have to broaden the usual term of "applications" if we want to be able to evaluate the impact of a design theory. The matter is not only to "apply" such theories, but also to use them as means to increase our ability to reinvent and regenerate industries and to deal with the so numerous challenges our contemporary societies are facing. How design theories could help us to explore and move the new frontiers of the unknown?

This first attempt to analyze applications and impacts of C-K design theory leads us to formulate the hypothesis that the evolutions of recent design theories are very closely link to the transformations of our contemporary society and the knowledge they use and produce. Design sciences would appear as a mean to rebuild new forms of epistemologies relevant for contemporary knowledge. 
Further researches are needed to explore the relationship between design theories and the transformations of "episteme" in our societies.

\section{References}

Agogué M (2012) Modéliser l'effet des biais cognitifs sur les dynamiques industrielles : innovation orpheline et architecte de l'inconnu. MINES ParisTech, Paris

Agogué M, Berthet E, Fredberg T, Le Masson P, Segrestin B, Stötzel M, Wiener M, Ystrom A (2013a) A contingency approach of open innovation intermediaries - the management principles of the "intermediary of the unknown". Paper presented at the European Academy of Management, Istambul,

Agogué M, Cassotti M (2012) Theory-driven experiments : modeling and testing fixation and stimulation effects on creativity. Paper presented at the 5 th Paris Workshop of the Design Theory SIG, Paris, , 30th january 2012,

Agogué M, Kazakçi A (2013) 10 years of C-K theory: a survey on the academic and industrial impacts of a design theory. In: Chakrabarti A, Blessing L (eds) Models and Theories of Design. Bangalore, pp 219-235

Agogué M, Kazakçi A, Hatchuel A, Le Masson P, Weil B, Poirel N, Cassotti M (2013b) The impact of type of examples on originality: Explaining fixation and stimulation effects. Journal of Creative Behavior.

Agogué M, Le Masson P, Robinson DKR (2012) Orphan Innovation, or when path-creation goes stale: missing entrepreneurs or missing innovation? Technology Analysis \& Strategic Management 24 (6):603-616.

Agogué M, Yström A, Le Masson P (2013c) Rethinking the Role of Intermediaries as an architect o f collective exploration and creation fo knowledge in open innovation. International Journal of Innovation Management 17 (2):24.

Arnoux F (2013) Intégrer des capacités d'innovation radicale : Le cas des mutations des systèmes d'énergie aéronautiques. MINES ParisTech, Paris

Arrighi P-A, Le Masson P, Weil B (2012) Breaking the Dilemma between robustnee and generativeness: an experimental assessment of a new software design suite. In: International Product Development Management Conference, Manchester, UK, 2012. p 20

Arrighi P-A, Le Masson P, Weil B (2013) From New Product Development (NPD) to New Design Process (NDP)? How new Computer Aided 
Design (CAD) tools lead to embedded learning and exploration in effective processes. In: International Product Development Management Conference, Paris, France, 2013. p 21

Ben Abbes A (2007) Cadrer des projets collaboratifs en structurant des champs d'innovation. Ecole des Mines de Paris, Paris

Benguigui J-M (2012) Les 10 ans de la théorie C-K : Revue de littérature. Paper presented at the AIMS,

Berthet E, Bretagnolle V, Segrestin B (2011) Introduction of semi-perennial forage crops in an intensive cereal plain to restore biodiversity: a need for collective management Journal for Sustainable Agriculture.

Blackler F (1995) Knowledge, Knowledge Work and Organizations : An Overview and Interpretation. Organization Studies 1995, 16/6:p. 10211046.

Brogard C, Joanny D (2010) Stratégies d'innovation pour préparer les moteurs d'avion vert de 2025. Rapports de l'option Ingénierie de la Conception. MINES ParisTech, Paris

Cogez P, Felk Y, Le Masson P, Weil B (2011) Absorptive Capacity for Radical Innovation: a Case Study in the Semiconductor Industry. In: IEEE International Technology Management Conference, San Jose, California, 2011.

Cogez P, Kokshagina O, Le Masson P, Weil B (2013) Industry-Wide Technology Road Mapping in Double Unknown - The Case of the Semiconductor Industry. In: IEEE International Technology Management Conference, San Jose, CA, 2013.

Defour M, Delaveau C, Dupas A (2010) Avionique. Des technologies innovantes au services des plus belles réussites aéronautiques. Gallimard Loisirs, Paris

Dym CL, Agogino AM, Eris O, Frey D, Leifer LJ (2005) Engineering Design Thinking, Teaching, and Learning. Journal of Engineering Education January 2005:103-120.

Ehrlenspiel K (1995) Intégrierte Produktentwicklung. Methoden für Prozessorganisation, Produkterstellung und Konstruktion. Carl Hanser Verlag, München, Wien

Elmquist M, Le Masson P (2009) The value of a 'failed' R\&D project: an emerging evaluation framework for building innovative capabilities. $R \& D$ Management 39 (2):136-152.

Elmquist M, Segrestin B (2009) Sustainable development through innovative design: lessons from the KCP method experimented with an automotive firm. International Journal of Automotive Technology and Management 9 (2):229-244.

Eris O (2005) Insisting on Truth at the Expense of Conceptualization: Can Engineering Portfolios Help? International Journal of Engineering Education 22 (3):551-559. 
Felk Y (2011) Evaluation et pilotage des activités de recherche pour la rupture dans la $R \& D$ centrale de STMicroelectronics : réviser les classiques du management de la recherche industrielle. MINES ParisTech, Paris

Felk Y, Le Masson P, Weil B, Hatchuel A (2011) Designing patent portfolio for disruptive innovation - a new methodology based on C-K theory. In: International Conference on Engineering Design, ICED'11, Copenhagen, Technical University of Denmark, 2011. p 12

Gardey de Soos P (ed) (2007) Conception innovante à la RATP : la méthode KCP. Cinq cas pratiques de conception innovante collective. Les rapports de la prospective, $n^{\circ} 146$. RATP, Paris

Gillier T, Piat G, Roussel B, Truchot P (2010) Managing Innovation Fields in a Cross-Industry Exploratory Partnership with $\mathrm{C}-\mathrm{K}$ Design Theory. Journal of product innovation management 27 (6):883-896.

Hatchuel A, Le Masson P, Weil B (2006) Building Innovation Capabilities. The Development of Design-Oriented Organizations. In: Hage J, Meeus M (eds) Innovation, Science and Industrial Change, the Handbook of Research. Oxford University Press, New-York, pp 294-312

Hatchuel A, Le Masson P, Weil B (2008) Learning to face the unknown and the emergent: a project-based critical learning perspective. In: European Academy of Management, Ljublana, 2008. p 19

Hatchuel A, Le Masson P, Weil B (2009) Design Theory and Collective Creativity: a Theoretical Framework to Evaluate KCP Process. In: International Conference on Engineering Design, ICED'09, 24-27 August 2009, Stanford CA, 2009.

Hatchuel A, Le Masson P, Weil B (2011) Teaching Innovative Design Reasoning: How C-K Theory Can Help to Overcome Fixation Effect. Artificial Intelligence for Engineering Design, Analysis and Manufacturing 25 (1):77-92.

Hatchuel A, Weil B (1995) Experts in Organization, a Knowledge-Based Perspective on Organizational Change (trans: Librecht L). Studies in Organization: Innovation, Technology and Organizations. Walter de Gruyter, New-York

Heymann M (2005) "Kunst" und Wissenchsaft in der Technik des 20. Jahrhunderts. Zur Geschichte der Konstruktionswissenschaft. Chronos Verlag, Zürich

Hooge S (2010) Performance de la R\&D en rupture et des stratégies d'innovation : Organisation, pilotage et modèle d'adhésion. MINES ParisTech, Paris

Hooge S, Hatchuel A (2008) Value indicators and monitoring in innovative PDM: a grounded approach. Paper presented at the International Product Development Management Conference, Hamburg,

Kokshagina O, Le Masson P, Weil B (2013a) How design theories enable the design of generic technologies: notion of generic concepts and Genericity building operators Paper presented at the International Conference on Engineering Design, ICED'13, Séoul, Korea, 
Kokshagina O, Le Masson P, Weil B, Cogez P (2013b) Platform emergence in double unknown (technology, markets): common unknown strategy. In: Çetindamar D, Daim T, Başoğlu N, Beyhan B (eds) Strategic planning decisions in the high tech industry. Springer, London, pp 90-120

Kroll E (2013) Design theory and conceptual design: contrasting functional decomposition and morphology with parameter analysis. Research in Engineering Design 24 (2):165-183.

Kroll E, Le Masson P, Weil B (2013) Modeling parameter analysis design moves with $\mathrm{C}-\mathrm{K}$ theory. Paper presented at the International Conference on Engineering Design, ICED'13, Séoul, Korea,

Le Masson P, Aggeri F, Barbier M, Caron P (2012a) The sustainable fibres of generative expectation management: The "building with hemp" case study. In: Barbier M, Elzen B (eds) System Innovations, Knowledge Regimes, and Design Practices towards Transitions for Sustainable Agriculture. INRA Editions, Paris, pp 226-251

Le Masson P, Cogez P, Felk Y, Weil B (2012b) Absorptive Capacity for Radical Innovation: A Case Study in the Semiconductor Industry. Advances in Technology and Innovation Management 1.

Le Masson P, Cogez P, Felk Y, Weil B (2012c) Revisiting Absorptive Capacity with a Design Perspective. International Journal of Knowledge Management Studies 5 (1/2):10-44.

Le Masson P, Gardey de Soos P (eds) (2007) La RATP et les enjeux de la compétition par l'innovation - un séminaire d'initiation à la conception innovante. Les rapports de la prospective, $\mathrm{n}^{\circ} 145$. RATP, Paris

Le Masson P, Weil B (2013) Design theories as languages for the unknown: insights from the German roots of systematic design (1840-1960). Research in Engineering Design 24 (2):105-126.

Le Masson P, Weil B, Hatchuel A (2010) Strategic Management of Innovation and Design. Cambridge University Press, Cambridge

Le Masson P, Weil B, Hatchuel A, Cogez P (2012d) Why aren't they locked in waiting games? Unlocking rules and the ecology of concepts in the semiconductor industry. . Technology Analysis \& Strategic Management 24 (6):617-630.

Le Masson P, Weil B, Kokshagina O (2013) A new perspective for risk management: a study of the design of generic technology with a matroid model in C-K theory. In: Taura T, Nagai Y (eds) Nara Workshop, Nara, Japan, 2013. p 15

Lenfle S (2012) Exploration, project evaluation and design theory: a rereading of the Manhattan case. International Journal of Managing Projects in Business 5 (3):486-507.

Pialot O, Legardeur J, Boujut J-F (2011) Towards a multi-input model, method and tool for early design phases in innovation. International Journal of Technology Management 55 (3):201-217. 
Reich Y, Hatchuel A, Shai O, Subrahmanian E (2010) A Theoretical Analysis of Creativity Methods in Engineering Design: Casting ASIT within C-K Theory Journal of Engineering Design:1-22.

Shai O, Reich Y, Hatchuel A, Subrahmanian E (2009) Creativity Theories and Scientific Discovery: a Study of C-K Theory and Infused Design. In: International Conference on Engineering Design, ICED'09, 24-27 August 2009, Stanford CA, 2009.

Shai O, Reich Y, Hatchuel A, Subrahmanian E (2013) Creativity and scientific discovery with infused design and its analysis with C-K theory. Research in Engineering Design 24 (2):201-214.

Sharif Ullah AMM, Mamunur Rashid M, Tamaki Ji (2011) On some unique features of C-K theory of design. CIRP Journal of Manufacturing Science and Technology in press.

Silberzahn P, Midler C (2008) Creating products in the absence of mar-kets: A robust design approach. Journal of Manufacturing Technology Management 19 (3):407-420.

Weil B (1999) Conception collective, coordination et savoirs, les rationalisations de la conception automobile. Thèse de doctorat en Ingénierie et Gestion, Ecole Nationale Supérieure des Mines de Paris, Paris

Zeiler W, Savanovic P (2009) Integral morphological Ck design approach for multidisciplinary building design. Architectural Engineering and Design Management 5 (4):193-214. 